\title{
Rhizospheric actinomycetes from organic crops of native potato (Solanum tuberosum): isolation, phenotypic characterization, molecular identification, and impact on biocontrol of Phytophthora infestans (Mont.) de Bary
}

\author{
Astrid Chumpitaz Bermejo ${ }^{1} \mathbb{D}$; Junior Caro Castro ${ }^{1} \mathbb{D}$; Wilbert Cruz Hilacondo ${ }^{2}$; \\ Jorge León Quispe ${ }^{1, *}$ (D) \\ 1 Laboratorio de Ecología Microbiana, Facultad de Ciencias Biológicas, Universidad Nacional Mayor de San Marcos, \\ Lima, Peru. \\ 2 Dirección de Desarrollo Tecnológico Agrario. Instituto Nacional de Innovación Agraria (INIA). Av. La Molina 1981, \\ Lima, Lima 15024, Peru.
}

Received February 25, 2020. Accepted May 31, 2020.

\begin{abstract}
Potato (Solanum tuberosum L.) is the fourth most consumed food crop in the world, whose production in Peru is diminished due to phytosanitary problems and high costs of chemical fertilizers. In the present work, 32 actinomycetes isolated from the rhizosphere of organic native potato crops collected in the town of Cabana, Lucanas, Ayacucho, were characterized phenotypically and evaluated for their in vitro antagonistic capacity against Oomycete phytopathogen Phytophthora infestans. The characterization tests showed that $97 \%$ of the actinomycetes were able to assimilate glucose, sucrose, and mannitol; as well as producing extracellular enzymes like amylases $(100 \%)$ and cellulases $(50 \%)$. Furthermore, the growth in laboratory culture was better in the range of $\mathrm{pH} 5.5-8.5$ and temperature $28-30{ }^{\circ} \mathrm{C}$. From the tests of antagonism in oat agar (71.9\%) and rye agar (31.2\%), three strains were selected according to the native potato variety were selected as CAB10-J2 (Ccompis), CAB9-CA4 (Cuchipa-akan) and CAB5F5 (Futis) with pathogen inhibition rates of $80.05,77.47$ and $37.5 \%$ respectively. The strains were identified by molecular tests as members of the genus Streptomyces and owners of polyketide synthase (PKS) genes. It is concluded that the rhizospheric actinomycetes of potato are producers of bioactive compounds capable of remarkably inhibiting the pathogen Phytophthora infestans, being able to be considered candidates in biological control programs of the "potato blight".
\end{abstract}

Keywords: actinobacteria; Phytophthora infestans; native potato; biocontrol of pests; antagonism.

\section{Introduction}

Potato (Solanum tuberosum L.) is the fourth most consumed crop in the world after wheat, corn, and rice, which are exceeds in terms of nutritional value. Among the potato producing countries, Peru is ranked 19th worldwide, being the main producer in Latin America, producing more than $\mathbf{4 . 5}$ million tons of this tuber and involving the participation of approximately 600,000 farmers distributed in 19 regions; being La Libertad, Huánuco, Puno, Junín and Ayacucho regions where ancestral crops are still carried out (Ministerio de Agricultura y Riego, 2017).
Potato cultivation is affected by limiting factors such as low tuber quality, soil impoverishment, indiscriminate use of agrochemicals, as well as the attack of insects and phytopathogenic organisms, resulting in a decrease in productivity and profitability of this tuber (Rico, 2009). On the other hand, due to exposure to various pests and pathogens, potato cultivation is an activity with high use of agrochemicals, substances that are toxic and dangerous for the farmer, the crop itself and the environment (Virmond et al., 2017).

A number of viral, fungal and bacterial agents, as well as nematodes, viroids and

Cite this article:

Chumpitaz, A.; Caro, J.; Cruz, W.; León, J. 2020. Rhizospheric actinomycetes from organic crops of native potato (Solanum tuberosum): isolation, phenotypic characterization, molecular identification, and impact on biocontrol of Phytophthora infestans (Mont.) de Bary. Scientia Agropecuaria 11(2): 223-231. 
oomycetes cause diseases to the potato crop (Bertschinger et al., 2017), highlighting among them, the Oomycete Phytophthora infestans (Mont.) De Bary, causal agent of the disease "late blight", and the main responsible for the deficit in yield and production, being able to cause from slight, moderate damages, until the total destruction of crops (Cardona-Piedrahita et al., 2016). The main sign of late blight is the burning of the foliage and the dry rot of the tubers (Steańczyk et al., 2016).

Currently, antagonistic microorganisms are used to control fungi and oomycetos in different types of crops, reducing the use of chemical methods that cause a negative environmental impact and induce the emergence of resistance in the future (Marín et al., 2013). Actinomycetes as Streptomyces sp. are capable of synthesizing bioactive compounds that inhibit the development of certain phytopathogens, thus providing protection to crops (Sinha et al., 2014). Some important studies include the control of phytopathogens such as Verticillium dahliae in cotton (Xue et al., 2013), Valsa mali in apple trees (Tang et al., 2015) and Fusarium oxysporum in soybeans (Mariastuti et al., 2018),

Some microorganisms such as Pseudomonas aeruginosa (De Vrieze et al., 2019), Lysobacter capsici (Puopoloet al., 2015), and the fungi Aureobasidium pullulans (Di Francesco et al., 2017) have been previously used in the control of Phytophthora infestans with great results. However, there are not many studies of the use of actinomycetes for the control of this pathogen. In this context, the aim of the present study is to contribute to the current knowledge about certain native strains of rhizospheric actionmycetes that have antagonistic capacity with potential use as biological controllers of Phytophthora infestans that affects potato crops.

\section{Materials and methods \\ Maintenance of Phytophthora infestans}

Phytophthora infestans, strain PHU-117, was maintained by subcultures of Rye Agar (HiMedia, India), incubating the plates at 28 ${ }^{\circ} \mathrm{C}$ from 5 to 7 days.

Sampling and transport to the laboratory Sampling took place in potato fields located in the town of Cabana, Lucanas, Ayacucho (14 $17^{\prime} 10^{\prime \prime}$ South Latitude; $73^{\circ} 57^{\prime} 51^{\prime \prime}$ West Longitude). The rhizospheric soil samples were collected from native potato plants of Canchán, Futis, Huayro, Cuchipa-akan, Ccompis and Chaska varieties, collecting $200 \mathrm{~g}$ portions of soil in ziploc bags, and then sent to the laboratory for processing
Isolation and selection of actinomycetes $10 \mathrm{~g}$ of soil from each dry sample was weighed, placing them inside a sterile bottle with $90 \mathrm{~mL}$ of $1.5 \%$ phenol saline solution and incubating at $30^{\circ} \mathrm{C}$ for 30 minutes. Subsequently, serial dilutions were prepared up to $10^{-4}$, sowing $100 \mu \mathrm{l}$ in plates with Oat Agar (BD Difco ${ }^{\mathrm{TM}}$, UK), Asparagine Agar (Merck, Germany), Czapeck Agar (Merck, Germany) and Casein-Starch Agar (HiMedia, India), all supplemented with nystatin $(50 \mu \mathrm{g} / \mathrm{mL})$ and nalidixic acid $(25 \mu \mathrm{g} / \mathrm{mL})$ (Sigma-Aldrich, USA), incubating them at $28^{\circ} \mathrm{C}$ from 15 to 20 days (Cisneros, 2016).

\section{Morphological characterization of isolated} actinomycetes

Actinomycetes were characterized macroscopically by observation of the colonies. The microscopic characterization was performed using microcultures, comparing the characteristics with those described in the Bergey's Manual of Systematic Bacteriology (Whitman et al., 2012). Selected strains were processed according to Colona et al. (2014) for observation by a scanning electron microscopy Inspect TM S50 (FEITM, Japan).

Assimilation of sugars and activity of hydrolytic enzymes

Glucose, sucrose, and mannitol metabolism tests were performed in ISP 9 medium with $1 \%$ of carbohydrates (w/v) (Caro, 2016). Likewise, the ability to produce amylase and cellulase were determined in Almidón Agar and Mandels-Reese Agar respectively, being evaluated according to Pérez et al. (2015) with Lugol and Congo red solutions. In all cases, the tests were evaluated up to 15 days.

\section{Growth depending on $\mathrm{pH}$ and temperature}

The tests were performed according to Calvo and Zúñiga (2010), using Oat Agar, evaluating its development at pHs $5.5 ; 7$ and 8.5 , and the temperatures of $4,28,30$ and 45 ${ }^{\circ} \mathrm{C}$, incubating them up to 10 days. The intensity of growth was evaluated at the end of the test period, measuring the diameter of the colonies, and recording the average size.

\section{Actinomycete antagonism against Phytophthora infestans}

In vitro antagonism was performed by dual culture (Pérez et al., 2015), sowing a suspension of actinomycete spores $\left(10^{5}\right.$ CFU/mL-1) in Oat Agar and Rye Agar plates at 3 equidistant sites, being in the center an inoculum of $P$. infestans. The plates were incubated at $28^{\circ} \mathrm{C}$ for 10 days. The diameters of the inhibition halos were measured with a millimeter ruler. The percent inhibition (PI) 
was calculated according to Ezziyyani et al. (2004): Percent inhibition $(P I)=\frac{R-r}{R} \times 100$

Where, $\mathbf{R}$ is the major radius (in $\mathrm{mm}$ ) of the Oomycete colony (control); $r$ is the smallest radius (in $\mathrm{mm}$ ) of the Oomycete in the dual culture. In all cases the radius measurement was the average of triplicate measurements.

\section{PKS gene detection and molecular identification of actinomycetes}

Selected strains which had the best antagonistic results were seeded in fermentation broths and incubated under stirring at $28^{\circ} \mathrm{C}$ for 7 days. Then, they were centrifuged at $14,000 \mathrm{rpm}$ for 10 minutes, adding $1 \mathrm{ml}$ of Lysozyme $(20 \mathrm{mg} / \mathrm{ml})$ (Sigma- Aldrich, USA) to the pellet, keeping in incubation at $56^{\circ} \mathrm{C}$ for $1 \mathrm{~h}$. DNA extraction was performed using GeneJET Genomic kit (Thermo Fisher Scientific, UK). For PCR amplification of PKS genes, primers $\mathrm{K} 1$ and M6R were used, whose sequences are 5'TSAAGTCSAACATCGGBCA-3' and 5'CGCAGGTTSCSGTACCAGTA-3'respectively, according to Chen et al. (2019) protocol, whose detection was revealed by agarose electrophoresis by visualization of the band at $700 \mathrm{bp}$ in a transilluminator (BioBase, China). Molecular identification was performed by PCR amplification of 16S rRNA gene using universal primers $27 \mathrm{~F}$ and 1429R, whose sequences are 5'AGAGTTTGATCMTGGCTCAG-3' and 5'GGTTACCTTGTTACGACTT-3'respectively, following the Parada et al. (2017) protocol. The amplicons were revealed by electrophoresis in agarose gels (1300 bp) and sent to Macrogen Inc. (Korea) for sequencing. The chromatograms were evaluated and edited in MEGA7 program, with multiple alignments of 16S rRNA sequences belonging to other actinomycetes of GenBank database, using Bacillus subtillis as an external group. The phylogenetic tree was constructed using Neighbor-Joining method (Kumar et al., 2016).

\section{Results and discussion}

Characterization of isolated actinomycetes

A total of 32 strains of rhizospheric actinomycetes from five native potato varieties were isolated, except for the Chaska variety. Table 1 shows the macroscopic characteristics of actinomycete colonies, which presented the following characteristics: Dry colonies strongly adhered to the medium and with a velvety, grainy, or powdery appearance, with or without pigment production (Figure $1 \mathrm{~A}$ and $1 \mathrm{~B}$ ).

Table 1

Macroscopic characterization of actinomycete colonies isolated from the native potato rhizosphere grown

\begin{tabular}{|c|c|c|c|c|c|c|}
\hline \multirow{2}{*}{ Strain } & \multirow{2}{*}{ Potato variety } & \multicolumn{5}{|c|}{ Colony characteristics } \\
\hline & & Shape & Pigment & Color & Edge & Elevation \\
\hline CAB3-C1 & Canchán & Regular & Green & White & Lobate & Convex \\
\hline CAB3-C2 & Canchán & Regular & NP & White & Entire & Convex \\
\hline CAB3-C3 & Canchán & Regular & NP & Gray & Entire & Convex \\
\hline CAB4-C1 & Canchán & irregular & NP & Gray & Entire & Convex \\
\hline CAB4-C2 & Canchán & Irregular & NP & Gray & Entire & Convex \\
\hline CAB4-C3 & Canchán & Regular & NP & Gray & Entire & Convex \\
\hline CAB4-C4 & Canchán & Irregular & Green & White & Entire & Convex \\
\hline CAB4-C5 & Canchán & Irregular & Green & Gray & Lobate & Convex \\
\hline CAB4-C6 & Canchán & Irregular & Green & Gray & Entire & Convex \\
\hline CAB5-F1 & Futis & Regular & Red & White & Lobate & Convex \\
\hline CAB5-F2 & Futis & Regular & Green & Gray & Lobate & Convex \\
\hline CAB5-F3 & Futis & Regular & Green & Gray & Entire & Convex \\
\hline CAB5-F4 & Futis & Irregular & Green & Gray & Entire & Convex \\
\hline CAB5-F5 & Futis & Irregular & Green & White & Entire & Convex \\
\hline CAB6-F1 & Futis & Regular & NP & Gray & Entire & Convex \\
\hline CAB7-H1 & Huayro & Irregular & Yellow & White & Entire & Convex \\
\hline CAB7-H2 & Huayro & Regular & Mustard & Gray & Lobate & Convex \\
\hline CAB7-H3 & Huayro & Regular & Mustard & Gray & Lobate & Convex \\
\hline CAB7-H4 & Huayro & Regular & NP & Gray & Lobate & Pulvinate \\
\hline CAB7-H5 & Huayro & Regular & NP & Red & Lobate & Pulvinate \\
\hline CAB8-H1 & Huayro & Regular & NP & Gray & Entire & Convex \\
\hline CAB8-H2 & Huayro & Regular & Green & Gray & Entire & Convex \\
\hline CAB9-CU1 & Cuchipa-akan & Regular & NP & White & Lobate & Acuminate \\
\hline CAB9-CU2 & Cuchipa-akan & Irregular & NP & Gray & Entire & Convex \\
\hline CAB9-CU3 & Cuchipa-akan & Irregular & NP & Gray & Lobate & Convex \\
\hline CAB9-CU4 & Cuchipa-akan & Regular & Green & Gray & Lobate & Convex \\
\hline CAB10-J1 & Ccompis & Regular & Red & White & Lobate & Convex \\
\hline CAB10-J2 & Ccompis & Irregular & Yellow & Gray & Entire & Pulvinate \\
\hline CAB10-J3 & Ccompis & Irregular & Yellow & Gray & Entire & Pulvinate \\
\hline CAB10-J4 & Ccompis & Regular & Mustard & White & Entire & Convex \\
\hline CAB10-J5 & Ccompis & Regular & Red & Gray & Lobate & Convex \\
\hline CAB10-J6 & Ccompis & Regular & NP & Gray & Lobate & Convex \\
\hline
\end{tabular}




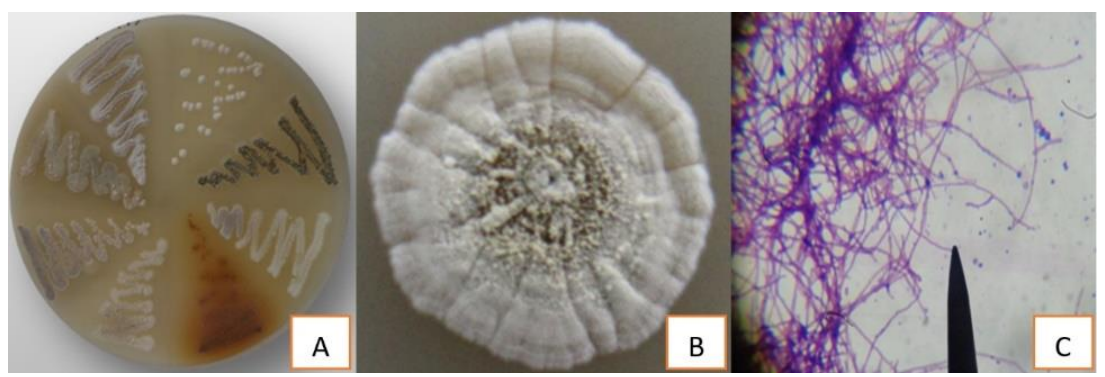

Figure 1. Various colonies of rhizospheric actinomycetes isolated from rhizosphere of native potatoes (A and B); and Gram staining observed under a microscope at 1000X magnification (C).

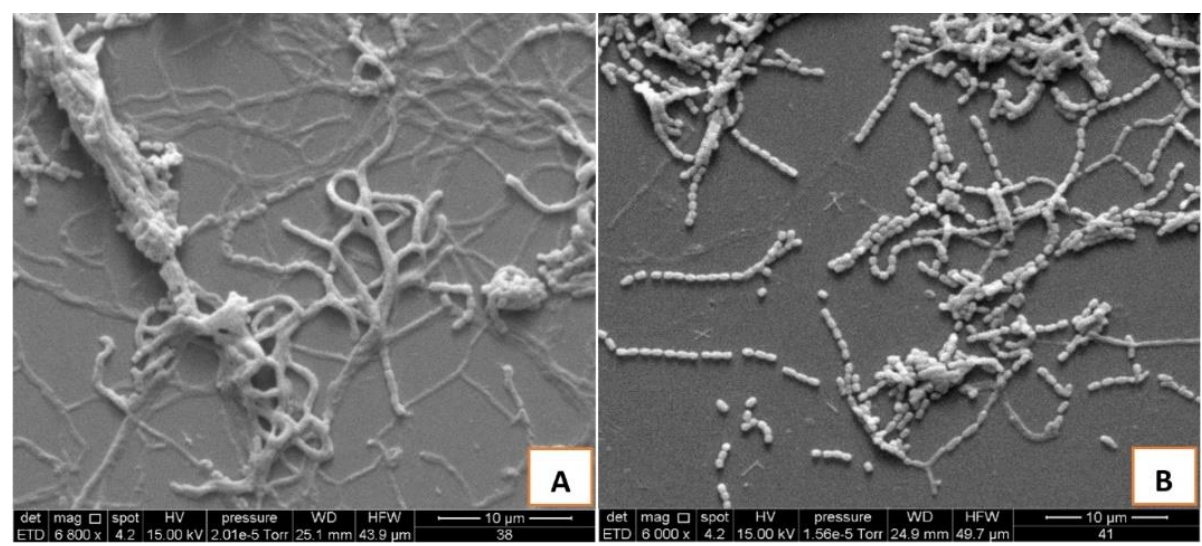

Figure 2. Actinomycetes seen by scanning electron microscope. A: strain CAB9-CA4; B: strain CAB10-J2. Magnification: $6800 \mathrm{X}$ and $6000 \mathrm{X}$, respectively.

The microscopic characterization by microculture showed fragmented mycelia and long spore chains. At Gram staining, Gram positive spiral filaments were observed (Figure 1C), typical of the genus Streptomyces. Likewise, the observation by scanning electron microscopy of selected strains allowed distinguishing branched filaments (Figure 2A) and presence of abundant spores (Figure 2B).

Oat Agar is not usual for the study of actinomycetes; however, it was used in this case following the recommendations of FrancoCorrea et al. (2010), who isolated important native strains of actinomycetes with potential application of Plant Growth Promoting Rhizobacteria (PGPR) from samples of rhizospheric soil.

\section{Sugar metabolism, hydrolytic activity and} growth depending on $\mathrm{pH}$ and temperature The results of each test are shown in Table 2. A big number $(97 \%)$, except for strain CAB7-H5, indicated that they were able to assimilate the three sugars. In contrast, Rico (2009), who also worked with isolated potato actinomycetes, only found that $15 \%$ of their isolates could use these sugars. The reason for this difference could be explained by the nature of the samples, since they come from different locations, soil types and physical-chemical factors of each place that influence the growth or activity of microorganisms (Li et al., 2018).

Regarding the ability to produce extracellular enzymes, all strains of actinomycetes showed amylolytic activity $(100 \%)$; in contrast, only $16(50 \%)$ showed cellulolytic activity. Actinomycetes CAB9-CU4 and CAB10-J2 had the best results of amylolytic and cellulolytic activity, respectively (Figure 3 ). In this regard, Caro (2016) reports similar results for producers of amylases $(89.8 \%)$ and cellulases $(26.5 \%)$.

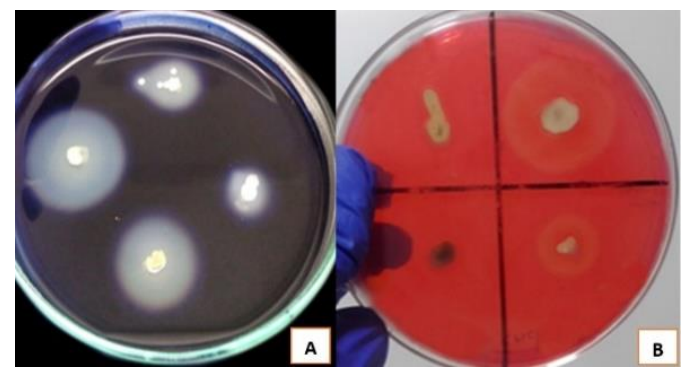

Figure 3. Rhizospheric actinomycetes of potato and its amylolytic (A) and cellulolytic (B) activity.

Also, the actinomycetes showed optimal growth in the $\mathrm{pH}$ range from 5.5 to 8.5 and at the incubation temperature of $28{ }^{\circ} \mathrm{C}$, reporting very few strains that could grow at low temperatures (Table 2). 
Table 2

Metabolic activity on carbohydrates, production of extracellular enzymes and growth based on pH and temperature of rhizospheric actinomycetes isolated from rhizosphere of native potatoes

\begin{tabular}{|c|c|c|c|c|c|c|c|c|c|c|c|}
\hline \multirow[t]{2}{*}{ Strain } & \multicolumn{3}{|c|}{ Carbohydrate Assimilation } & \multicolumn{2}{|c|}{$\begin{array}{c}\begin{array}{c}\text { Synthesis of hydrolytic } \\
\text { enzymes }\end{array} \\
\end{array}$} & \multicolumn{3}{|c|}{$\mathrm{pH}$} & \multicolumn{3}{|c|}{ Temperature $\left({ }^{\circ} \mathrm{C}\right)$} \\
\hline & Gluc & Sac & Man & Cellulase & Amylase & 5,5 & 7,0 & 8,5 & 4 & 28 & 45 \\
\hline CAB3-C1 & + & + & + & - & +++ & ++ & +++ & ++ & - & +++ & - \\
\hline CAB3-C2 & + & + & + & - & +++ & ++ & ++ & ++ & - & ++ & - \\
\hline CAB3-C3 & + & + & + & ++ & +++ & ++ & ++ & ++ & - & +++ & ++ \\
\hline CAB4-C1 & + & + & + & ++ & +++ & ++ & ++ & ++ & - & +++ & - \\
\hline CAB4-C2 & + & + & + & +++ & +++ & ++ & ++ & + & - & ++ & -- \\
\hline CAB4-C3 & + & + & + & +++ & +++ & ++ & +++ & ++ & - & +++ & - \\
\hline CAB4-C4 & + & + & + & - & +++ & + & ++ & ++ & - & ++ & - \\
\hline CAB4-C5 & + & + & + & - & +++ & ++ & ++ & + & - & ++ & - \\
\hline CAB4-C6 & + & + & + & - & + & ++ & +++ & ++ & - & +++ & - \\
\hline CAB5-F1 & + & + & + & ++ & +++ & ++ & +++ & ++ & - & +++ & - \\
\hline CAB5-F2 & + & + & + & - & +++ & ++ & ++ & ++ & - & ++ & - \\
\hline CAB5-F3 & + & + & + & - & +++ & ++ & +++ & ++ & - & ++ & - \\
\hline CAB5-F4 & + & + & + & - & ++ & ++ & +++ & ++ & - & ++ & - \\
\hline CAB5-F5 & + & + & + & - & ++ & + & ++ & ++ & - & +++ & - \\
\hline CAB6-F1 & + & + & + & ++ & +++ & + & +++ & ++ & - & ++ & - \\
\hline CAB7-H1 & + & + & + & - & +++ & ++ & ++ & ++ & - & +++ & - \\
\hline CAB7-H2 & + & + & + & ++ & +++ & ++ & +++ & ++ & - & +++ & - \\
\hline CAB7-H3 & + & + & + & + & +++ & ++ & +++ & ++ & - & ++ & - \\
\hline CAB7-H4 & + & + & + & ++ & ++ & ++ & +++ & ++ & + & +++ & - \\
\hline CAB7-H5 & - & - & - & + & ++ & ++ & ++ & ++ & - & ++ & + \\
\hline CAB8-H1 & + & + & + & ++ & +++ & ++ & +++ & + & - & +++ & - \\
\hline CAB8-H2 & + & + & + & - & +++ & ++ & ++ & ++ & - & ++ & - \\
\hline CAB9-CU1 & + & + & + & + & ++ & ++ & +++ & ++ & - & +++ & - \\
\hline CAB9-CU2 & + & + & + & - & ++ & ++ & +++ & ++ & - & ++ & - \\
\hline CAB9-CU3 & + & + & + & - & ++ & ++ & +++ & ++ & - & ++ & - \\
\hline CAB9-CU4 & + & + & + & - & +++ & ++ & +++ & ++ & - & +++ & - \\
\hline CAB10-J1 & + & + & + & - & ++ & ++ & +++ & + & + & +++ & - \\
\hline CAB10-J2 & + & + & + & - & +++ & ++ & +++ & ++ & ++ & +++ & - \\
\hline CAB10-J3 & + & + & + & +++ & ++ & ++ & +++ & ++ & - & +++ & ++ \\
\hline CAB10-J4 & + & + & + & +++ & ++ & ++ & ++ & ++ & - & +++ & - \\
\hline CAB10-J5 & + & + & + & +++ & ++ & ++ & +++ & ++ & - & ++ & - \\
\hline CAB10-J6 & + & + & + & +++ & ++ & ++ & +++ & ++ & + & +++ & - \\
\hline
\end{tabular}

Carbohydrate Assimilation: positive $=+;$ negative $=-$

Synthesis of hydrolytic enzymes: negative $=-;$ low $=+$; moderate $=++;$ good $=+++$

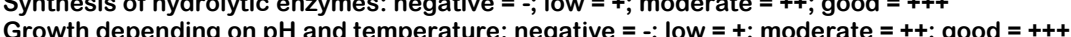


Table 3

Rhizospheric actinomycetes isolated from native potatoes and their antagonistic activity to Phytophthora infestans in two culture media

\begin{tabular}{|c|c|c|c|}
\hline \multirow{2}{*}{ Strain } & \multirow{2}{*}{ Variety } & \multicolumn{2}{|c|}{ Percent inhibition (\%) } \\
\hline & & Oat Agar & Rye Agar \\
\hline CAB3-C1 & Canchán & 50,0 & 0 \\
\hline CAB3-C2 & Canchán & 13,3 & 0 \\
\hline САВ3-С3 & Canchán & 0 & 0 \\
\hline CAB4-C1 & Canchán & 33,3 & 0 \\
\hline CAB4-C2 & Canchán & 26,6 & 37,5 \\
\hline CAB4-C3 & Canchán & 16,6 & 16,6 \\
\hline CAB4-C4 & Canchán & 33,3 & 32,8 \\
\hline CAB4-C5 & Canchán & 57,14 & 38,0 \\
\hline CAB4-C6 & Canchán & 11,11 & 0 \\
\hline CAB5-F1 & Futis & 16,6 & 0 \\
\hline CAB5-F2 & Futis & 44,4 & 21,05 \\
\hline CAB5-F3 & Futis & 16,0 & 0 \\
\hline CAB5-F4 & Futis & 44,4 & 0 \\
\hline CAB5-F5 & Futis & 37,5 & 0 \\
\hline CAB6-F1 & Futis & 0 & 0 \\
\hline CAB7-H1 & Huayro & 37,3 & 37,3 \\
\hline CAB7-H2 & Huayro & 0 & 0 \\
\hline САВ7-H3 & Huayro & 0 & 0 \\
\hline CAB7-H4 & Huayro & 0 & 0 \\
\hline CAB7-H5 & Huayro & 16,6 & 0 \\
\hline CAB8-H1 & Huayro & 37,73 & 0 \\
\hline CAB8-H2 & Huayro & 33,3 & 0 \\
\hline CAB9-CU1 & Cuchipa-akan & 30,43 & 0 \\
\hline CAB9-CU2 & Cuchipa-akan & 58,33 & 0 \\
\hline CAB9-CU3 & Cuchipa-akan & 0 & 0 \\
\hline CAB9-CU4 & Cuchipa-akan & 77,47 & 30,16 \\
\hline CAB10-J1 & Ccompis & 39,81 & 42,31 \\
\hline CAB10-J2 & Ccompis & 80,05 & 43,90 \\
\hline CAB10-J3 & Ccompis & 0 & 0 \\
\hline CAB10-J4 & Ccompis & 40,0 & 0 \\
\hline CAB10-J5 & Ccompis & 60,0 & 0 \\
\hline CAB10-J6 & Ccompis & 60,0 & 31,07 \\
\hline
\end{tabular}

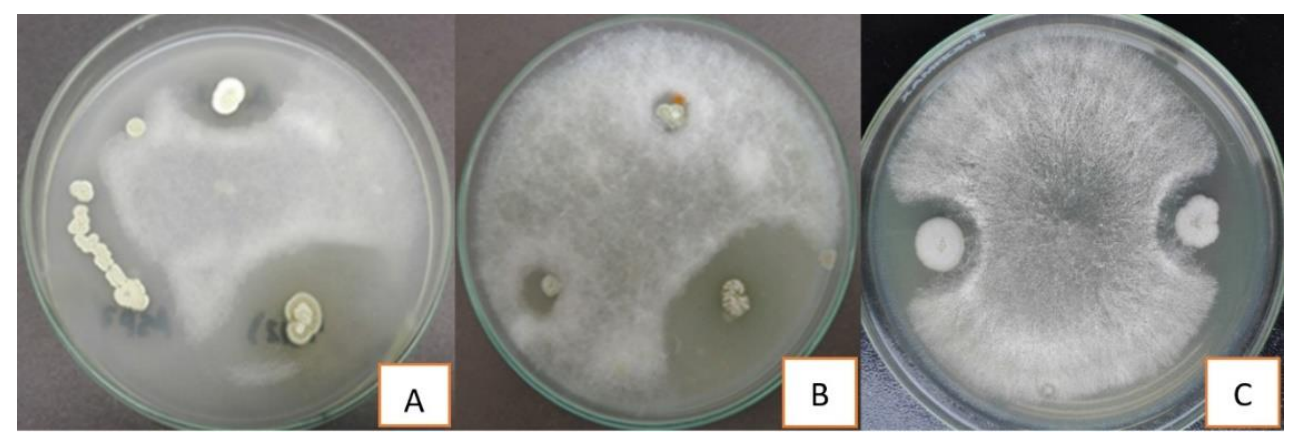

Figure 4. Anti-Phytophthora infestans activity shown by the actinomycetesCAB9-CA4 (A), CAB10-J2 (B) and CAB5-F5 (C).

Rico (2009) reports that, at a $\mathrm{pH} 5.5$ and a temperature of $10^{\circ} \mathrm{C}, 65 \%$ of its isolates can be developed, although with limitations in their development, presenting colonies of smaller size than at higher temperatures. On the other hand, Cisneros (2016) reports that none of its isolates could develop at acidic $\mathrm{pHs}$ and low temperatures. These results indicate that the physical-chemical characteristics of the soil are determinants for the development of actinomycetes, and that they must be taken into consideration when conducting tests in field of biological control of pests

\section{Actinomycete antagonist activity against $\boldsymbol{P}$. infestans}

The results of antagonistic activity tests are shown in Table 3 . From all isolated actinomycetes $(n=32), 25(78.1 \%)$ showed activity against $P$. infestans at least in one of the two culture media used here. In Oat Agar, it was possible to observe $25(78.1 \%)$ of strains with positive activity, while in Centeno Agar only $10(31.25 \%)$ had a positive result. The percentages of inhibition obtained varied in the range from 13.33 to $80.05 \%$, being strains CAB10-J2 (80.05\%), CAB9-CU4 (77.47\%) and CAB5-F5 (37.5\%) who pre-sented the highest values of inhibition per-centages (Figure 4).

Performing a comparative analysis, Fonseca et al. (2011) find that, of the total actinomycetes isolated from organic residues of chipaca (Bidens pilosa), only $32 \%$ presented antagonistic activity against $P$. infestans. It should be noted that these 
tests were performed on Rye Agar. Likewise, Pérez et al. (2015) reported that $42.4 \%$ of their isolated actinomycetes from compost showed $P$. infestans inhibitory activity in Rye Agar. Another similar study was carried out by Caro (2016), indicates that $46.9 \%$ of actinomycetes isolated from potato rhizosphere had positive activity against $P$. infestans in Rye Agar. In the present work, we obtained results of antagonisms superior to those already mentioned; however, it is necessary to specify that these results come from the tests in Oat Agar, which had not been used before for antagonism tests, being a different situation with Rye Agar because it possesses sitosterol, which is necessary for the development of this pathogen (Fonseca et al., 2011).

Some other microorganisms with direct antiPhytophthora activity have been described. Potential biocontrol candidates for which inhibitory activity against $\boldsymbol{P}$. infestans was demonstrated include Trichoderma sp., Pythium oligandrum, Bacillus sp. and Pseudomonas sp. (Mariastuti et al., 2018; De Vrieze et al., 2019), which could have in vitro inhibition results superior to those obtained in this study; however, it is necessary to emphasize that in many of them the secondary metabolite that causes the antagonistic effect wasused directly, which is not explored in this study, but it is an important aspect to consider for future researches.

\section{PKS gene detection and molecular identifi- cation}

Three of the actinomycetes which had the best results were selected for the molecular tests, CAB10-J2, CAB9-CU2 and CAB5-F5, having the 700 bp band of PKS gene (Figure $5)$.

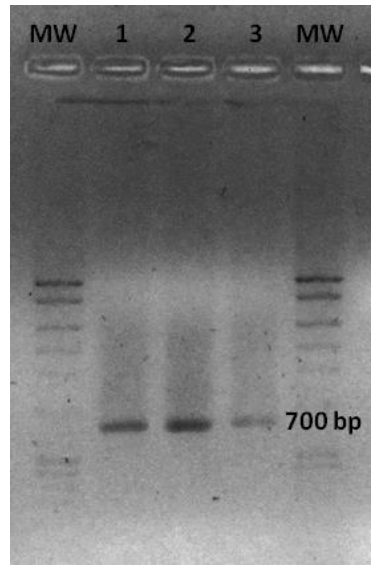

Figure 5. PCR electrophoresis gel indicating PKS gene amplification (700 bp). Lane 1: CAB10-J2. Lane 2: CAB9CU2. Lane 3: CAB5-F5. MW: Molecular-weight size marker.

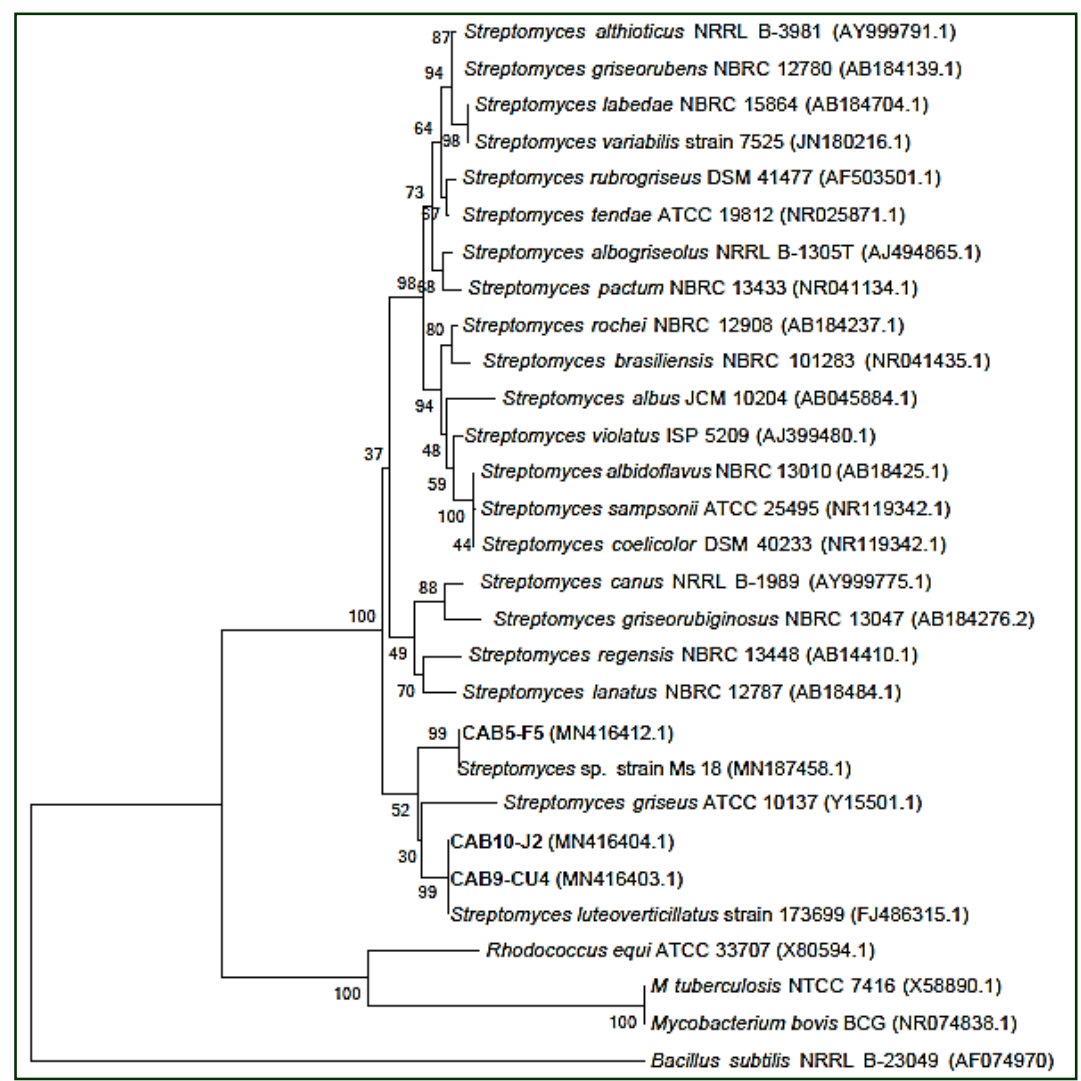

Figure 6. Phylogenetic tree of $16 \mathrm{~S}$ rDNA gen of actinomycetes isolated from native potato constructed with MEGA7. 
These were selected for sequencing of $16 \mathrm{~S}$ rRNA gen, identifying strains CAB10-J2 and CAB9-CU2 as Streptomyces luteoverticillatus with $99 \%$ of similarity, while strain CAB5F5 was identified as Streptomyces sp. with $99 \%$ of similarity (Figure 6 ). The sequences of these three strains were deposited in the GenBank database (Access numbers: MN416404.1, MN416403.1 and MN4164 12.1).

About $S$. Iuteoverticillatus, it is known as a major producer of antifungal compounds like Carbazomycin B (Feng et al., 2019), which would explain the positive antagonistic effect on $P$. infestans described in this work.

\section{Conclusions}

The results of this work provide important data from in vitro tests, although additional studies of Streptomyces and its secondary compounds are required that lead to effective practical formulations for field application. The potential of Streptomyces spp. in the control of plant diseases has been the subject of many studies; on the other hand, reports against $P$. infestans are scarce. In this sense, our results represent a first step towards the effort to incorporate actinomycetes into biocontrol programs of late potato blight, being and important starting point for the elaboration of bioinoculants of easy elaboration and low cost to increase the yield and reduce the losses by pests of this tuber.

\section{Acknowledgment}

To Vicerrectorado de Investigación y Posgrado (VRIP) of National University of San Marcos, for its financing through the Undergraduate Thesis Promotion Fund (Project: B17100244a) (RR N ${ }^{\circ}$ 06369-R-17) and Alejandro Delgado León, potato farmer from the community of Cabana, for providing tuber samples and the identification of native potato varieties.

\section{ORCID}

A. Chumpitaz iD https://orcid.org/0000-0002-5932-3176

J. Caro iD https://orcid.org/0000-0002-8890-6119

W. Cruz (iD http://orcid.org/0000-0003-0314-4686

J. León (iD https://orcid.org/0000-0001-5865-5374

\section{References}

Bertschinger, L.; Buhler, L.; Dupuis, B.; et al. 2017. Incomplete Infection of Secondarily Infected Potato Plants - an Environment Dependent Underestimated Mechanism in Plant Virology. Front. Plant Sci. 8: 74.

Calvo, P.; Zúñiga, D. 2010. Caracterización fisiológica de cepas de Bacillus spp. aisladas de la rizósfera de papa (Solanum tuberosum). Ecología Aplicada 9(1): 31-39.

Cardona-Piedrahita, L.; Castaño-Zapata, J.; CeballosAguirre, N. 2016. Epidemiología del tizón tardío [Phytophthora infestans (Mont.) de Bary] en quince introducciones de tomate silvestre. Revista U.D.C.A Actualidad \& Divulgación Científica 19(1): 45-54.

Caro, J. 2016. Capacidad antagonista de actinomicetos aislados de la rizósfera de la papa (Solanum tuberosum sp. andigena) para el control de hongos fitopatógenos de importancia agrícola. Tesis de grado, Universidad Nacional Mayor de San Marcos, Lima. Perú. 120 pp.

Cisneros, J. 2016. Aislamiento y selección de actinomicetos rizosféricos con potencial aplicación como bioinoculante en el cultivo de Solanum tuberosum sp. andigena (Papa). Tesis de grado, Universidad Nacional Mayor de San Marcos, Lima. Perú. $93 \mathrm{pp}$.

Chen, P.; Zhang, C.; Ju, X.; et al. 2019. Community Composition and Metabolic Potential of Endophytic Actinobacteria From Coastal Salt Marsh Plants in Jiangsu, China. Front Microbiol. 10: 1063.

Colona, E.; Galindo, N.; León, J.; et al. 2014. Desarrollo de un método para la observación de actinomicetos por microscopía electrónica de barrido. En XXIII Reunión Científica ICBAR, Perú, 12-14 ago, 2014.

De Vrieze, M.; Gloor, R.; Codina, J.; et al. 2019. Biocontrol Activity of Three Pseudomonas in a Newly Assembled Collection of Phytophthora infestans Isolates. Phytopathology 109(9): 1555-1565.

Di Francesco, A.; Milella, F.; Mari, M.; et al. 2017. A preliminary investigation into Aureobasidium pullulans as a potential biocontrol agent against Phytophthora infestans of tomato. Biological control 114: 144-149.

Ezziyyani, M.; Pérez, C.; Requena, M.; et al. 2004. Biocontrol por Streptomyces rochei- Ziyani, de la podredumbre del pimiento (Capsicum annum L.) causada por Phytophthora capsici. Anales de Biología 26: 69-78.

Feng, Z.; Chen, G., Zhang, J.; et al. 2019. Characterization and Complete Genome Analysis of the Carbazomycin B-Producing Strain Streptomyces luteoverticillatus SZJ61. Current Microbiology 76: 982-987.

Fonseca, Y.; Castellanos, D.; León, T. 2011. Efecto antagónico in vitro de actinomicetos aislados de purines de chipaca (Bidens pilosa L.) frente a Phytophthora infestans (Mont) de Bary. Rev. Fac. Nal. Agr. Medellín 64(2): 6111-6119.

Franco-Correa, M. 2009. Utilización de los actinomicetos en procesos de biofertilización. Revista Peruana de Biología 16(2): 239-242.

Kumar, S.; Stecher, G.; Tamura, K. 2016. MEGA7: Molecular Evolutionary Genetics Analysis Version 7.0 for Bigger Datasets. Molecular Biology and Evolution 33(7):1870-1874.

Li, L.; Xu, M.; Eyabuk, M.; et al. 2018. Factors affecting soil microbial biomass and functional diversity with the application of organic amendments in three contrasting cropland soils during a field experiment. PLoS One 13(9): e0203812.

Mariastuti, H.; Listiyowati, S.; Wahyudi, A. 2018. Antifungal activity of soybean rhizosphere actinomycetes producing bioactive compounds against Fusarium oxysporum. Biodiversitas 19(6): 2127-2133.

Marín, M.; Wong, I.; García, G.; et al. 2013. Actividad antagónica in vitro de Tsukamurella paurometabola C-924 frente a fitopatógenos. Rev. Protección Veg. 28(2): 132-137.

Ministerio de Agricultura y Riego. 2016. Papa: Características de la Producción Nacional y de la Comercialización en Lima Metropolitana. Ministerio de Agricultura y Riego, Perú. 13 pp.

Parada, R.; Marguet, E.; Vallejo, M. 2017. Aislamiento y caracterización parcial de actinomicetos de suelos con actividad antimicrobiana contra bacterias multidrogo-resistentes. Rev. Colomb. Biotecnol. 19(2): 15-23.

Pérez, F.; León, J.; Galindo, N. 2015. Actinomicetos aislados del compost y su actividad antagonista a fitopatógenos de la papa (Solanum tuberosum spp. 
andigena Hawkes). Rev. Mex. Fitopatol. 33(2): 116139.

Puopolo, G.; Palmieri, M.; Giovannini, O.; et al. 2015. Impact of temperature on the survival and the biocontrol efficacy of Lysobacter capsici AZ78 against Phytophthora infestans. BioControl 60: 681689.

Rico, M. 2009. Capacidad promotora de crecimiento vegetal por bacterias del género Azotobacter y Actinomicetos aislados de cultivos de Solanum tuberosum Linnaeus, 1753 (papa) cultivados en zonas altoandinas del Perú. Tesis de grado, Universidad Nacional Mayor de San Marcos, Lima. Perú. 152 pp.

Sinha, K.; Hegde, R.; Kush, A. 2014. Exploration on native actinomycetes strains and their potential against fungal plant pathogens. Int. J. Curr. Microbiol. App. Sci. 3(11): 37-45.

Stefańczyk, E.; Sobkowiak, S.; Brylińska, M; et al. 2016. Diversity of Fusarium spp. associated with dry rot of potato tubers in Poland. European Journal of Plant Pathology 145: 871-884.

Tang, J.; Xue, Z.; Daroch, M.; et al. 2015. Impact of continuous Salvia miltiorrhiza cropping on rhizosphere actinomycetes and fungi communities. Annals of Microbiology 65: 1267-1275.

Virmond, E.; Kawakami, J.; Souza-Diaz, J. 2017. Seedpotato production through sprouts and field multiplication and cultivar performance in organic system. Hortic. Bras. 35(3): 335-342.

Whitman, W.; Goodfellow, M.; Kampfer, P.; et al. 2012. Bergey's manual of determinative bacteriology. Volume 5: The Actinobacteria. 2nd edition. Springer Science \& Business Media, USA. 1750 pp.

Xue, L.; Xue, Q.; Chen, Q.; et al. 2013. Isolation and evaluation of rhizosphere actinomycetes with potential application for biocontrol of Verticillium wilt of cotton. Crop Protection 43: 231-240. 